\title{
Sistem Informasi Penerimaan Peserta Didik Baru Berbasis Web
}

\author{
Mia Rosmiati \\ Program Studi Sistem Informasi, Universitas Bina Sarana Informatika \\ mia.mrm@bsi.ac.id
}

\begin{abstract}
In the era of digital media development, which is increasingly rapid, almost everyone of all ages is in dire need of digital media that is connected to the internet so that people can provide and receive information quickly. With the implementation of school closures since March 16, 2020 due to the global Covid-19 pandemic, schools are carrying out online learning activities. With these conditions, the school must have an appropriate marketing strategy, the school must be able to carry out the process of admitting new students. So that many prospective students will register at the school even though the school is still not open. The solution that can be done is to develop a website-based school information system where prospective new students can access the website anywhere and anytime so that they can receive information about the school quickly, precisely, and accurately and carry out the registration process as prospective students without having to come to school. The development of a new student admission information system is designed using the Waterfall Method with the stages being carried out, namely needs analysis, design, programming, testing, and support or maintenance.
\end{abstract}

\section{Keywords: Program Design, Student Acceptance}

Abstrak: Di era perkembangan media digital yang semakin pesat saat ini hampir setiap kalangan dari berbagai tingkat usia sangat membutuhkan media digital yang terhubung dengan internet sehingga masyarakat dapat memberikan dan menerima informasi dengan cepat. Dengan diberlakukannya penutupan sekolah sejak 16 Maret 2020 dikarenakan pandemi global Covid-19 sekolah melaksanakan kegiatan pembelajaran secara online. Dengan kondisi seperti ini sekolah harus memiliki strategi marketing yang sesuai, sekolah harus dapat menjalankan proses penerimaan peserta didik baru. Sehingga banyak calon siswa yang akan mendaftar di sekolah tersebut walaupun sekolah masih belum dibuka. Solusi yang dapat dilakukan adalah mengembangkan sistem informasi sekolah berbasis website dimana calon peserta didik baru dapat mengakses website tersebut dimanapun dan kapanpun sehingga mereka dapat menerima informasi tentang sekolah secara cepat, tepat, dan akurat dan melakukan proses pendaftaran sebagai calon siswa tanpa harus datang ke sekolah. Pengembangan sistem informasi penerimaan peserta didik baru di rancangan menggunakan Metode Waterfall dengan tahapan yang dilakukan yaitu analisis kebutuhan, desain, pembuatan kode program, pengujian, dan pendukung atau pemeliharaan.

Kata kunci: Perancangan Program, Penerimaan Peserta Didik

This is an open access article distributed under the Creative Commons Attribution License, which permits unrestricted use, distribution, and reproduction in any medium, provided the original work is properly cited. O2019 by author and IJSE-Indonesian Journal on Software Engineering.

\section{A. PENDAHULUAN}

Di era perkembangan media digital yang semakin pesat saat ini sangat membantu setiap kegiatan masyarakat dalam kehidupan sehari-hari. Hampir di setiap kalangan dari berbagai tingkat usia sangat membutuhkan media digital yang terhubung dengan internet sehingga masyarakat dapat memberikan dan menerima informasi dengan cepat.

Pada kondisi sekarang ketika Indonesia sedang mengalami Pandemi Global Covid-19. Menurut informasi yang didapatkan dari https://www.cnnindonesia.com/ pada tanggal 2 Maret 2020 Presiden Joko Widodo mengatakan ada seorang Warga Negara Jepang yang positif Virus Corona pernah berkontak dengan Warga Negara Indonesia (WNI) yang akhirnya WNI tersebut 
ikut terpapar virus corona. Dengan terjadinya pandemi ini di Indonesia menyebabkan sebagian Pemerintah Provinsi mengambil langkah untuk menutup sekolah selama dua pekan. Dalam https://www.tempo.co/ Gubernur DKI Jakarta Anies Baswedan mengatakan bahwa penutupan sekolah di Indonesia disebabkan oleh wabah virus corona merupakan langkah pertama yang diambil untuk menghambat penyebaran virus ini. Penutupan sekolah dimulai pada hari Senin, 16 Maret 2020 sampai dua minggu ke depan. Namun sampai saat ini sekolah-sekolah belum dibuka dikarenakan situasi saat ini masih dalam tahap Pembatasan Sosial Berskala Besar (PSBB) Transisi.

Dengan diberlakukannya penutupan sekolah sejak 16 Maret 2020 semua sekolah khususnya yang berada di Jakarta melaksanakan kegiatan pembelajaran dan pengajaran jarak jauh yang dilakukan di rumah masing-masing. Baik guru maupun murid tidak datang ke sekolah tetapi proses belajar mengajar dilakukan dengan jarak jauh. Menjelang akhir tahun ajaran, sekolah juga sedang bersiap untuk membuka tahun ajaran baru yang sudah diputuskan oleh Kemendtrian Pendidikan dan Kebudayaan bahawa tahun ajaran baru akan dimulai pada 13 Juli 2020. Dengan kondisi seperti ini sekolah-sekolah terutama sekolah swasta harus memiliki strategi marketing yang cocok dan sesuai dengan adanya pembatasan sosial berskala besar, bagaimana sekolah tetap dapat menjalankan proses penerimaan peserta didik baru. Sehingga banyak calon siswa yang akan mendaftar di sekolah tersebut walaupun saat ini sekolah masih belum dibuka.

Penelitian sebelumnya yang sudah dilakukan oleh (Amin, 2017) memiliki permasalahan yaitu sistem penerimaan siswa baru yang digunakan sampai sekarang masih menggunakan sistem manual, panitia pendaftaran melakukan pencatatan data dalam sebuah buku atau arsip. Penelitian ini menghasilkan sebuah sistem informasi penerimaan peserta didik baru berbasis web. Sistem pendaftaran peserta didik baru berbasis web dapat memudahkan calon siswa untuk melakukan pendaftaran, menghemat waktu dan biaya dibandingkan jika datang langsung ke sekolah, dan dengan sistem informasi informasi penerimaan siswa baru, diharapkan dapat membantu dan mempermudah dalam pengolahan peserta didik.

Sedangkan penelitian yang dilakukan oleh (Aulawi \& Srinawati, 2019), menghasilkan sebuah sistem informasi penerimaan peserta didik baru berbasis web. Permasalahan yang terjadi yaitu Proses penerimaan siswa baru (PSB) yang masih menggunakan sistem konvensional, sehingga calon siswa terkadang kesulitan mendapatkan informasi untuk melakukan proses pendaftaran. Proses administrasi juga cenderung lambat, karena data belum terintegrasi dan terkelola dengan baik. Proses ini juga masih menggunakan arsip dalam bentuk fisik yang rentan mengalami kerusakan atau bahkan hilang. Untuk dapat mengatasi permasalahan yang terjadi pada pendaftaran siswa baru di SMP Plus Babussalam dibuatlah perancangan dan pembangunan aplikasi Sistem Informasi Penerimaan Siswa Baru Berbasis Web. Metode yang digunakan untuk pembangunan sistem informasi menggunakan Model Prototype dengan pendekatan sistem berorientasi objek yang dimodelkan menggunakan UML (Unified Modelling Language). Hasil akhir dari perancangan dan pembangunan sistem informasi ini adalah adanya sebuah aplikasi yang dapat memberi kemudahan akses informasi dan proses pendaftaran sehingga proses administrasi.

Berdasarkan latar belakang masalah di atas dalam penelitian ini akan dibuat sebuah sistem informasi untuk penerimaan peserta didik baru berbasis website dimana calon peserta didik baru dapat mengakses website tersebut dimana pun dan kapan pun sehingga mereka dapat menerima informasi-informasi tentang sekolah secara cepat, tepat, dan akurat dan melakukan proses pendaftaran sebagai calon siswa tanpa harus datang ke sekolah. Diharapkan dengan adanya sistem ini dapat memberikan solusi bagi sekolah-sekolah swasta dalam proses penerimaan peserta didik untuk tahun ajaran 2020/2021 mendatang.

\section{B. TINJAUAN PUSTAKA}

\section{Website}

Menurut (Bekti, 2015), "Website adalah kumpulan halaman-halaman yang digunakan untuk menampilkan informasi teks, gambar diam atau gerak, animasi, suara, dan atau gabungan dari semuanya, baik bersifat statis maupun dinamis yang membentuk satu rangkaian bangunan yang saling terkait, yang masing-masing dihubungkan dengan jaringan-jaringan halaman" 
Sedangkan menurut Fristanto dalam (Rohman \& Kurniawan, 2017), "Website adalah lokasi di internet yang berfungsi sebagai media penyampaian informasi, komunikasi, entertainment atau transaksi."

\section{Internet}

Menurut (Sibero, 2016), "Internet (Interconnected Network) adalah jaringan komputer yang menghubungkan antar jaringan secara global, internet dapat juga disebut jaringan dalam suatu jaringan yang luas".

Sedangkan menurut (Iskandar, 2018), Internet berasal dari bahasa yunani "inter" yang berarti "antara". Internet merupakan singkatan dari interconnection-networking yang merupakan sistem jaringan yang menghubungkan tiap-tiap komputer secara global, global Transmission Control Protocol/Internet Protocol Suite (TCP/IP) sebagai protokol pertukaran paket (packet switching communication protocol) untuk melayani miliaran pengguna di seluruh dunia. Koneksi yang menghubungkan masing-masing komputer tersebut memiliki standar yang digunakan yang disebut Internet Protocol Suite disingkat TCP/IP. Komputer yang terhubung ke internet akan memiliki kemampuan melakukan pertukaran data dengan cepat.

\section{Web Server}

Menurut (Rerung, 2018), "Web server adalah software yang menjadi tulang belakang dari World Wide Web (WWW".

Sedangkan menurut Sadeli dalam (Nisa \& Supriatna, 2015), "Web server adalah sebuah perangkat lunak server yang berfungsi menerima permintaan HTTP dan HTTPS dari client yang dikenal dengan web browser yang umumnya berbentuk dokumen HTML".

\section{Web Browser}

Sibero dalam (Nisa \& Supriatna, 2015), mengemukakan bahwa web browser adalah aplikasi perangkat lunak yang digunakan untuk mengambil mengambil dan menyajikan sumber informasi web.

Beberapa contoh web browser yang sering digunakan diantaranya seperti mozilla firefox, internet explorer, google chrome, UC browser, dan lain-lain.

\section{Teknologi Website}

Teknologi yang berhubungan dengan antarmuka untuk menjembatani server web dan klien mereka. Yang termasuk ke dalam teknologi website, yaitu :

a. PHP

Menurut (Madcoms, 2016), "PHP adalah bahasa script yang ditanamkan atau disisipkan kedalam HTML". PHP digunakan untuk membuat program situs web dinamis. PHP juga digunakan untuk membuat sebuah CMS.

b. HTML

Menurut (Bekti, 2015), "HTML adalah bahasa pemrograman yang digunakan untuk mendesain sebuah halaman web". Sedangkan menurut (Abdulloh, 2015), "HTML adalah singkatan dari hypertext markup language, yaitu tag-tag yang membuat dan mengatur struktur website".

Menurut Kustiyahningsih dan Anamsia dalam (Sasongko, 2017), "File-file HTML mengandung perintah-perintah yang diterjemahkan oleh browser yang ada dikomputer client (user) sehingga bentuknya dapat ditampilkan secara visual dikomputer pengguna (user)."

\section{ERD}

Menurut (Sukamto \& Shalahuddin, 2014), "Entity Relationship Diagram (ERD) adalah model yang banyak digunakan dalam pemodelan basis data, ERD dikembangkan berdasarkan teori himpunan dalam bidang matematika". Elemen-elemen diagram hubungan entitas adalah sebagai berikut :

a. Entity

Entity adalah apa saja yang ada di dalam sistem, baik sistem nyata maupun abstrak tempat data tersimpan. Entitas dinamakan dengan kata benda dan dikelompokkan dalam empat jenis nama, yaitu orang, benda, lokasi, kejadian (terdapat unsur waktu di dalamnya). 
b. Relationship

Relationship diberi nama kata kerja yang dapat memudahkan untuk membaca relasinya. Relationship adalah hubungan yang terjadi antars entitas.

c. Attribute value

Attribut value atau nilai atribut adalah suatu occorrence tertentu dari sebuah attribute didalam suatu entity atau relationship.

d. Derajat Relationship (Relationship Degree)

Derajat relationship adalah jumlah entitas yang berpartisipasi dalam satu relationship.

\section{Struktur Navigasi}

Menurut (Ardiansyah, 2016), "Struktur Navigasi merupakan alur dari suatu program yang menggambarkan rancangan hubungan antara halaman yang berbeda sehingga memudahkan proses pengelompokkan seluruh elemen-elemen website".

Sedangkan menurut Sutopo dalam (Imaniawan \& Wati, 2017), "Dalam pengembangan web, terdapat beberapa model navigasi dasar, yang harus dikenal dengan baik oleh desaigner, karena setiap model navigasi dapat memberikan solusi tuk kebutuhan yang berbeda". Macam-macam struktur navigasi antara lain:

a. Linear Navigation

Model Linear navigation digunakan oleh sebagian besar Website. Setiap halaman diberikan informasi secara sekuensial.

b. Hierarki model

Hierarki model diadaptasi dari top- down design. Konsep navigasi ini dimulai dari satu node yang menjadi home page. Dari home page dapat dibuat beberapa cabang kehalamhalaman utama. Apabila di perlukan, dari tiap halaman utama dapat dikembangkan menjadi beberapa cabang lagi. Hal ini seperti struktur organisasi dalam perusahaan.

c. Spoke-and-hub model

Spoke and hub model menggunakan satu node untuk berhubungan dengan node lain. Model ini terdiri dua macam link, yaitu dari home page ke halaman tertentu, dan dari halaman itu kembali ke home page.

d. Full Web Model

Full web model memberikan kemampuan hyperlink yang banyak. Full web model digunakan karena user dapat mengakses semua topik dengan sub topik dengan cepat. Namun kelemahan dari model ini, yaitu dapat berakibat user kehilangan cara untuk kembali ke topik sebelumnya.

\section{BackBox Testing}

Menurut (Puspitasari, 2016), "Pengujian dilakukan untuk meminimalkan kesalahan (error) dan memastikan keluaran yang dihasilkan sesuai dengan yang diinginkan". Sedangkan menurut (Wahyuningrum \& Januarita, 2017), "Pengujian metode black box merupakan pengujian terhadap fungsionalitas input/output dari suatu perangkat lunak".

Pengujian yang digunakan untuk menguji sistem ini adalah metode black

box. Menurut (Riadi, 2016), "Pengujian black box terfokus pada persyaratan fungsional perangkat lunak".

\section{METODE PENELITIAN}

Dengan menggunakan metode penelitian yang tepat diharapkan bisa mendapatkan informasi yang tepat dan akurat. Adapun metode penelitian yang digunakan adalah sebagai berikut:

\section{Metode Pengembangan Perangkat Lunak}

Menurut Rosa dan Salahuddin dalam (Susilowati \& Informatika, 2017), "Model Pengembangan Perangkat Lunak atau yang biasa disebut System Development Life Cycle (SDLC) adalah proses memodifikasi suatu sistem perangkat lunak dengan menggunakan model-model dan metodologi yang digunakan untuk mengembangkan sitem perangkat lunak sebelumnya".

Dalam metode ini penulis menggunakan Metode Air Terjun atau biasa disebut dengan Waterfall. Adapun tahapan yang penulis lakukan dalam Metode Waterfall adalah:

a. Analisis Sistem 
Dalam tahapan ini dilakukan pengumpalan data, identifikasi masalah, usulan pemecahan masalah dan analisa kebutuhan sistem yang ada agar dapat difokuskan untuk pembuatan website yang nantinya akan dihasilka sistem yang sesuai dengan kebutuhan dan harapan user.

b. Desain

Tahap ini dilakukan dengan membuat desain struktur data, desain antar muka, berdasarkan kebutuhan yang sudah dianalisa. Untu desai tampilan website terdiri dari halaman back end, front end dan tabel-tabel di database. Hal ini dilakukan agar dapat diimplementasikan menjadi program pada tahap pengkodean.

c. Pembuatan Kode Program

Dalam pembuatan kode program dibuat kode program berdasarkan desain yang telah dibuat sebelumnya dan diimplementasikan menjadi program utuh agar dapat dimanfaatkan sesuai tujuannya. Adapun bahasa pemrograman yang digunakan, yaitu PHP, CSS dan Javascript.

d. Pengujian

Pengujian dilakukan terhadap tools-tools yang telah dibuat dalam website untuk memastikan output yang dihasilkan sesuai dengan yang diinginkan dan untuk meminimalisir kesalahan (error). Dalam tahap pengujian ini digunakan teknik black box testing (pengujian kotak hitam).

e. Pendukung (Support) atau Pemeliharaan (Maintenance)

Tahapan ini dilakukan dengan pemeliharaan terhadap program yang telah diterapkan apabila terdapat kesalahan atau perubahan yang tidak terdeteksi pada saat pengujian.

\section{Metode Pengumpulan Data}

Tahapan-tahapan yang penulis lakukan dalam metode pengumpulan data yaitu:

a. Observasi

Tahapan dalam penelitian ini dengan cara melakukan pengamatan-pengamatan baik secara langsung maupun secara online terhadap kegiatan-kegiatan yang berhubungan dengan masalah penerimaan peserta didik baru. Hasil dari pengamatan tersebut diketahui permasalahan yang terjadi dan kebutuhan yang akan digunakan dalam sistem penerimaan peserta didik baru.

b. Studi Pustaka

Selain melakukan metode observasi, metode yang dilakukan adalah mencari referensi melalui artikel ilmiah dalam jurnal, buku, ebook, dan juga mencari informasi secara online terkait dengan penerimaan peserta didik baru.

\section{HASIL DAN PEMBAHASAN}

\section{Analisis Kebutuhan Pengguna}

Analisisi kebutuhan dilakukan untuk mengetahui kebutuhan apa saja yang diperlukan dalam sistem penerimaan peserta didik baru berbasis website ini. Adapun pengguna website ini dibagi menjadi 2 kategori yaitu user yang merupakan calon peserta didik baru dan administrator yang merupakan admin website yang ada di sekolah.

a. User

User dapat melihat beranda, profil, sekolah dan galeri

User wajib melakukan login ketika ingin melakukan proses pendaftaran

User dapat melakukan pendaftaran

User dapat melakukan konfirmasi untuk pembayaran

User dapat melakukan logout untuk keluar dari sistem

b. Administrator

Administrator wajib melakukan login untuk dapat mengelola website

Administrator dapat mengelola data user

Administrator dapat mengelola data pendaftaran siswa baru

Administrator dapat mengelola data galeri

Administrator dapat mengelola data pembayaran

Administrator dapat mengelola laporan

Administrator dapat melakukan logout untuk keluar dari sistem 
IJSE - Indonesian Journal on Software Engineering, Vol.6, No.2, Desember 2020, 182-194

\section{Entity Relationship Diagram (ERD)}

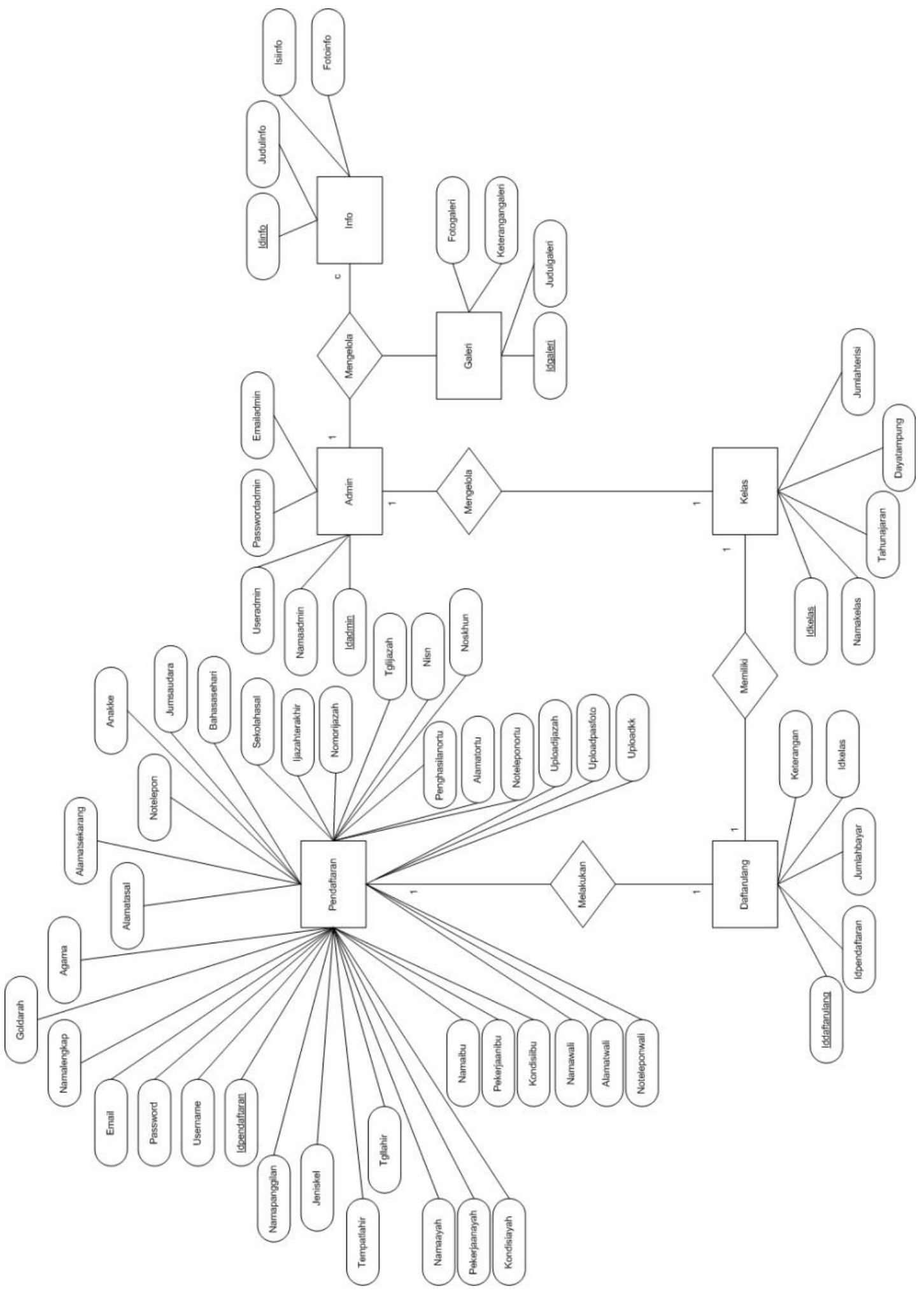

Gambar 1. ERD Penerimaan Peserta Didik Baru 
ERD yang dibuat dalam perancangan sistem informasi penerimaan peserta didik baru ini dapat dilihat pada Gambar 1. Entitas yang terbentuk berdasarkan hasil analisis kebutuhan yaitu pendaftaran, admin, galeri, kelas, daftarulang, dan info.

\section{Logical Record Structure (LRS)}

\begin{tabular}{|l|}
\hline \multicolumn{1}{|c|}{ Pendaftaran } \\
\hline \\
Idpendafatran * \\
Username \\
Password \\
Email \\
Namalengkap \\
Namapanggilan \\
Jeniskel \\
Tempatlahir \\
Tgllahir \\
Goldarah \\
Agama \\
Alamatasal \\
Alamatsekarang \\
Notelepon \\
Anakke \\
Jumsaudara \\
Bahasasehari \\
Sekolahasal \\
ljazahterakhir \\
Noijazah \\
Tglijazah \\
Nisn \\
Noskhun \\
Namaayah \\
Pekerjaanayah \\
Kondisiayah \\
Namaibu \\
Pekerjaanibu \\
Kondisiibu \\
Penghasilanortu \\
Alamatortu \\
Noteleponortu \\
Namawali \\
Alamatwali \\
Noteleponwali \\
Uploadijazah \\
Uploadkk \\
Uploadpasfoto \\
\\
\hline
\end{tabular}

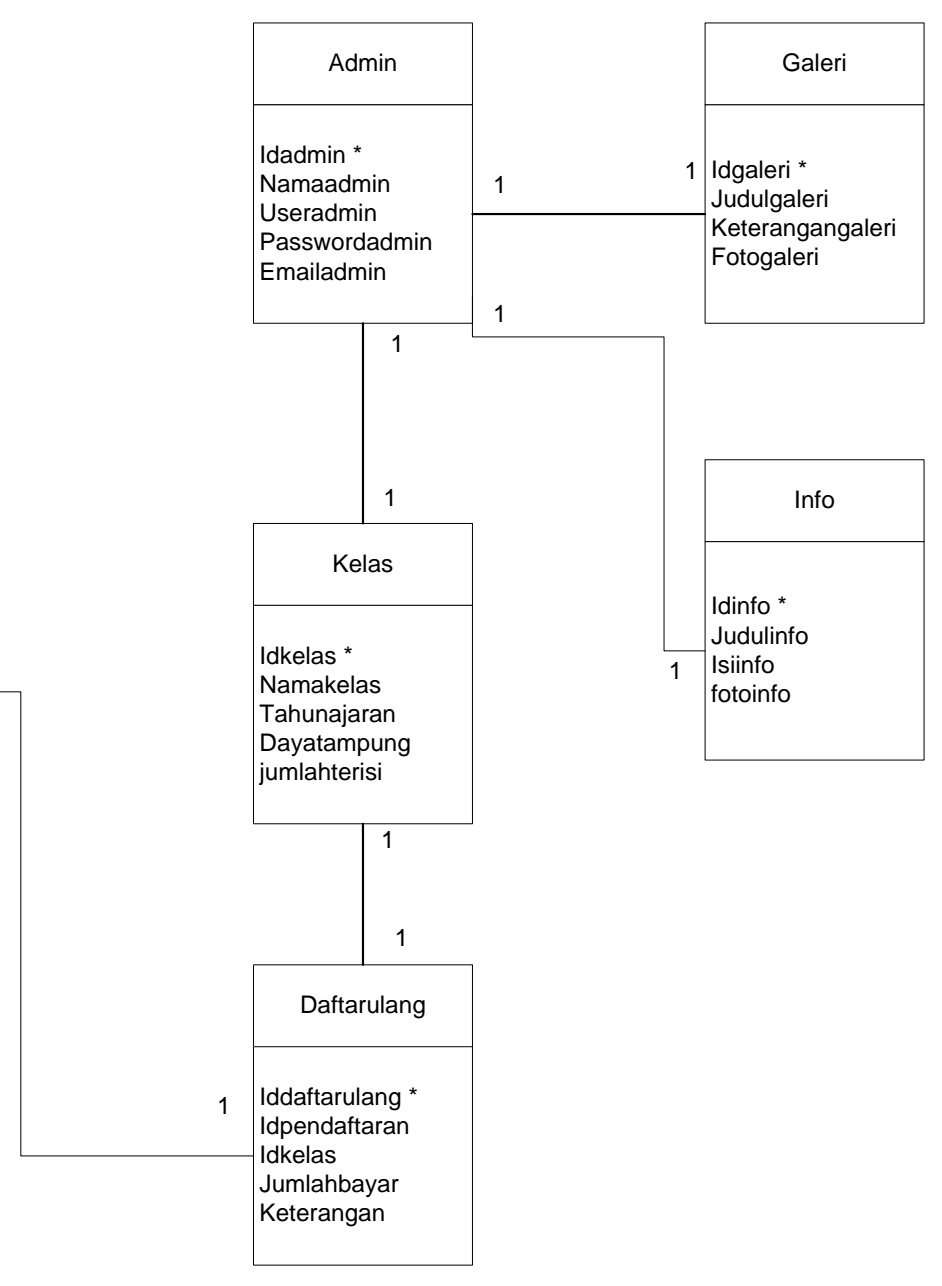

1

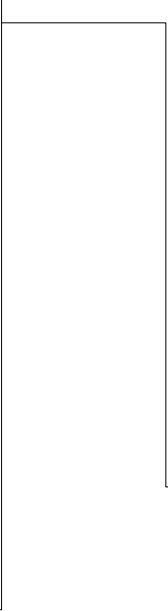

Gambar 2. LRS Penerimaan Peserta Didik Baru

Berdasarkan ERD yang sudah terbentuk, selanjutnya ditransformasikan dalam bentuk diagram LRS yang dapat dilihat pada Gambar 2. 
IJSE - Indonesian Journal on Software Engineering, Vol.6, No.2, Desember 2020, 182-194

\section{Struktur Navigasi}

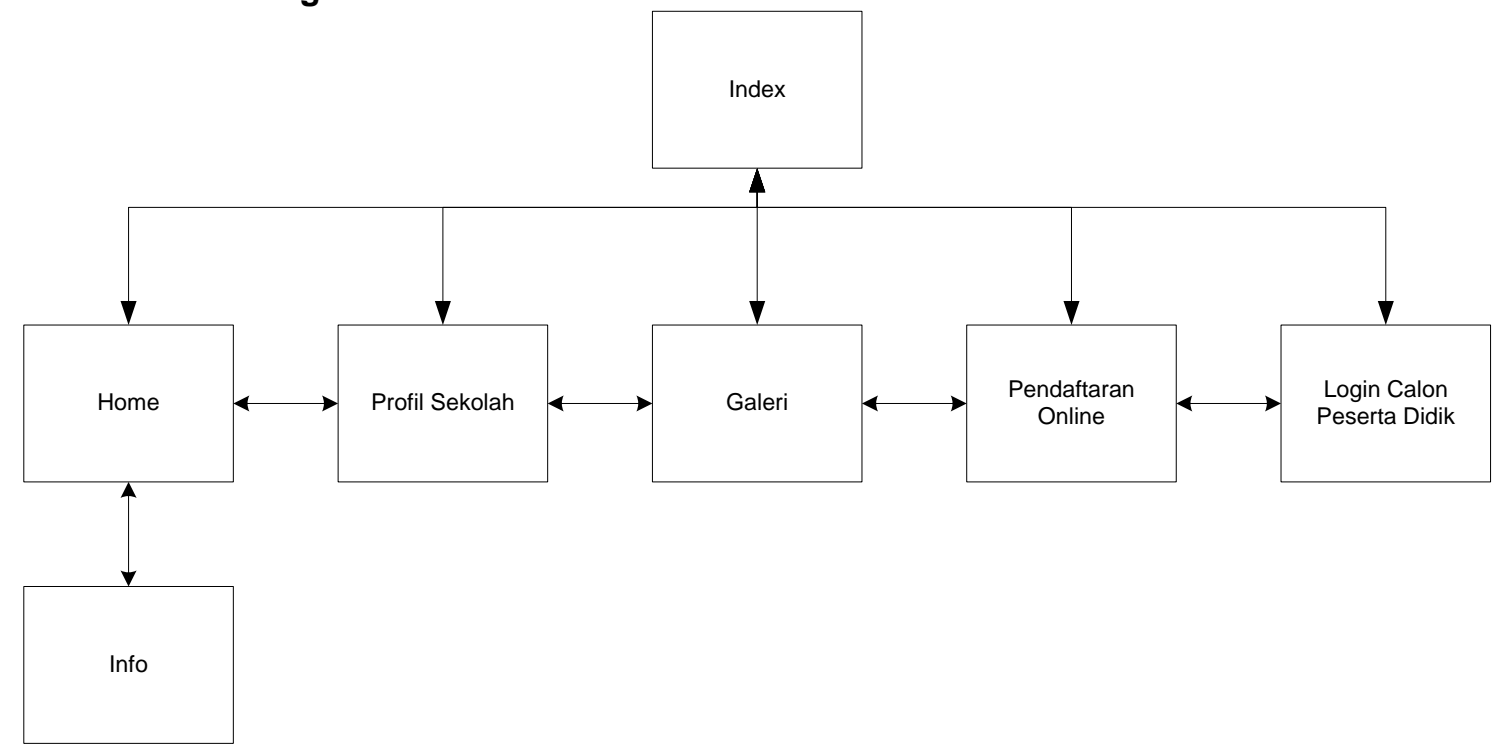

Gambar 3. Struktur Navigasi Halaman Pengunjung

Pada Gambar 3 merupakan rancangan menu dari halaman website pengunjung yang ada di sistem informasi penerimaan peserta didik baru. Halaman awal pengunjung terdiri dari halaman Home, Profil Sekolah, Galeri, Pendaftaran Online, dan Login Calon Peserta Didik. 


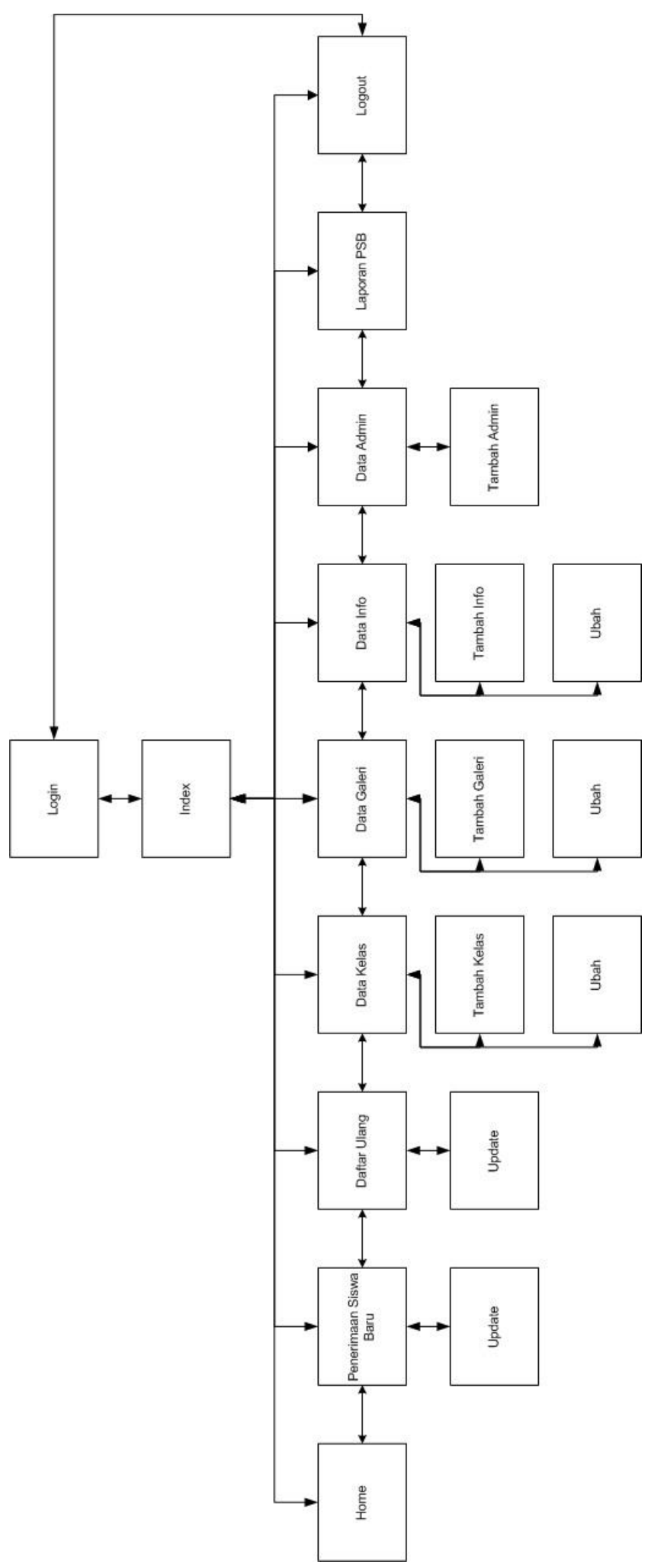

Gambar 4. Struktur Navigasi Halaman Administrator

Pada Gambar 4 merupakan rancangan menu dari halaman website administrator yang ada di sistem informasi penerimaan peserta didik baru. Halaman awal administrator terdiri dari halaman Home, Penerimaan Siswa Baru, Daftar Ulang, Data Kelas, Data Galeri, Data Info, Data Admin, Laporan PSB dan Logout. 
IJSE - Indonesian Journal on Software Engineering, Vol.6, No.2, Desember 2020, 182-194

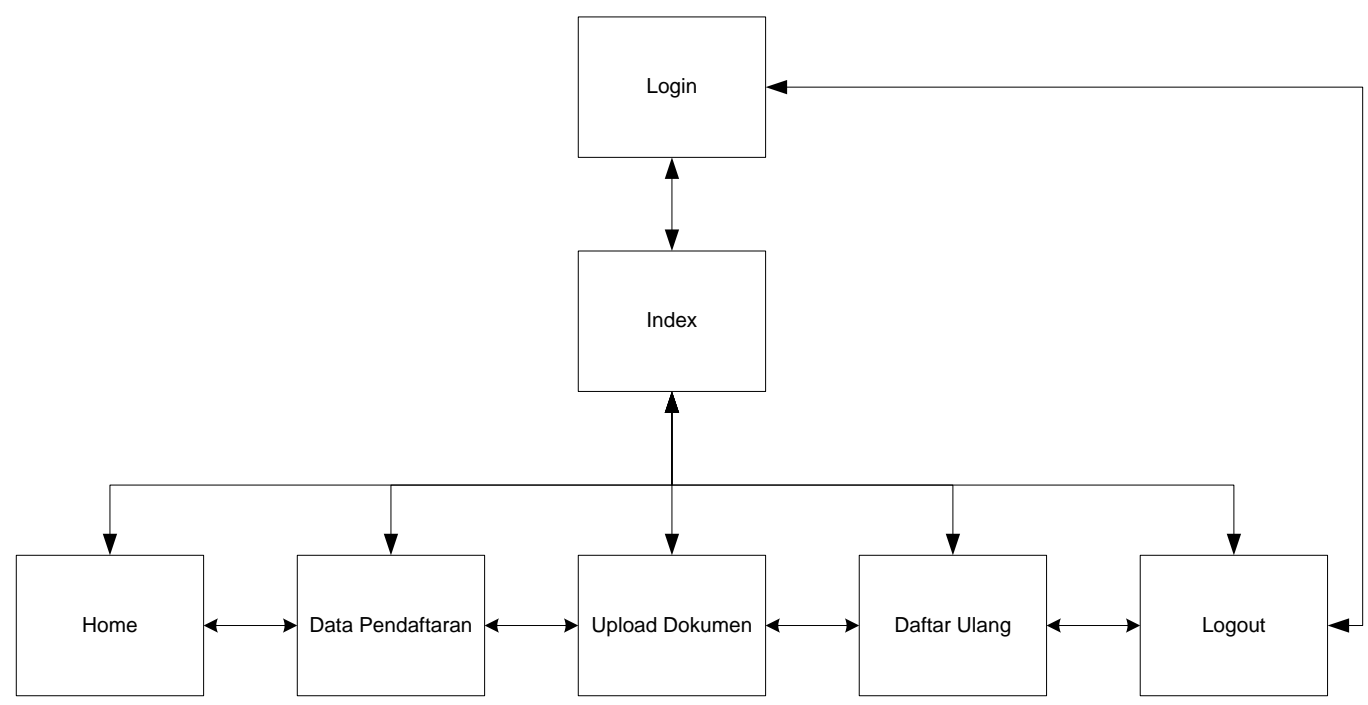

Gambar 5. Struktur Navigasi Halaman Calon Peserta Didik

Pada Gambar 5 merupakan rancangan menu dari halaman website calon peserta didik yang ada di sistem informasi penerimaan peserta didik baru. Halaman awal calon peserta didik terdiri dari halaman Home, Data Pendaftaran, Upload Dokumen, Daftar Ulang, dan Logout.

\section{Implementasi}

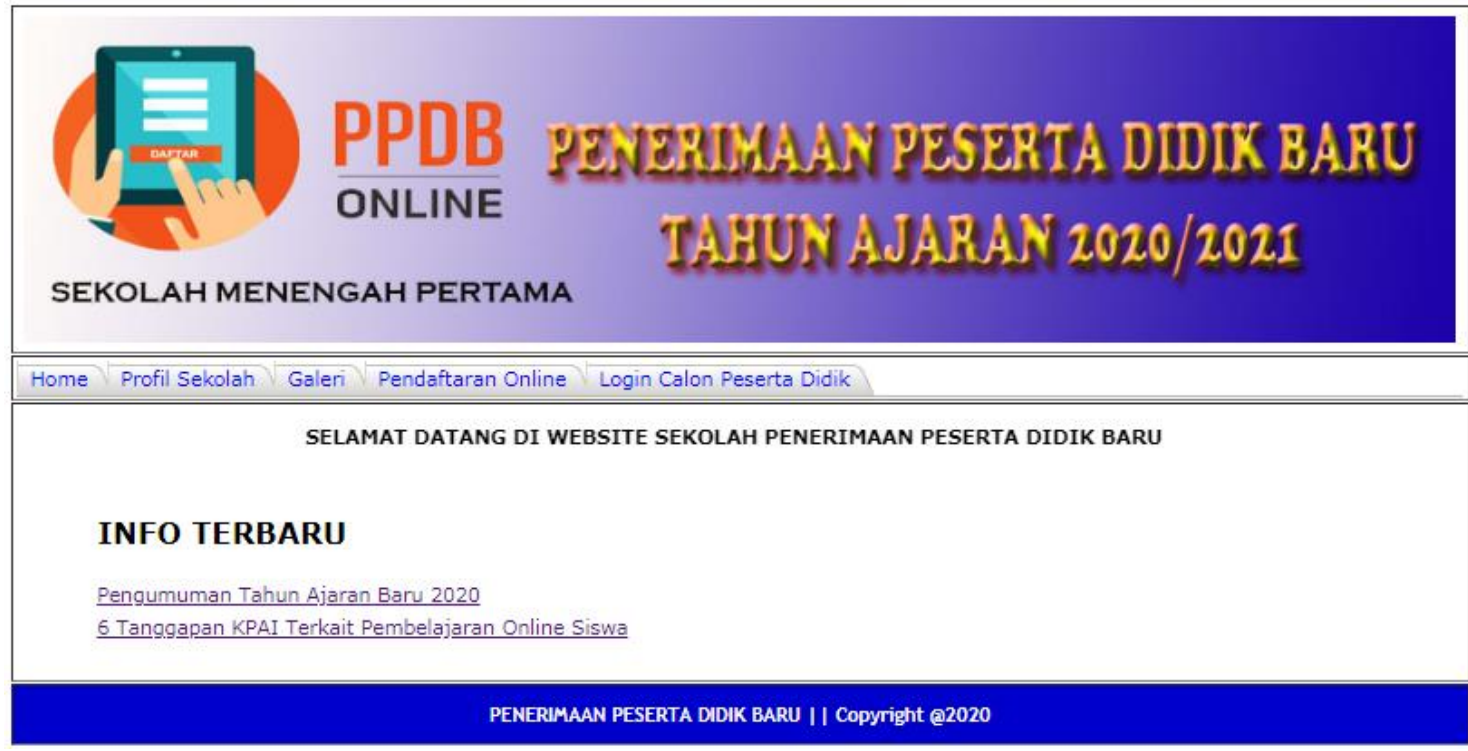

Gambar 6. Halaman Home Pengunjung 


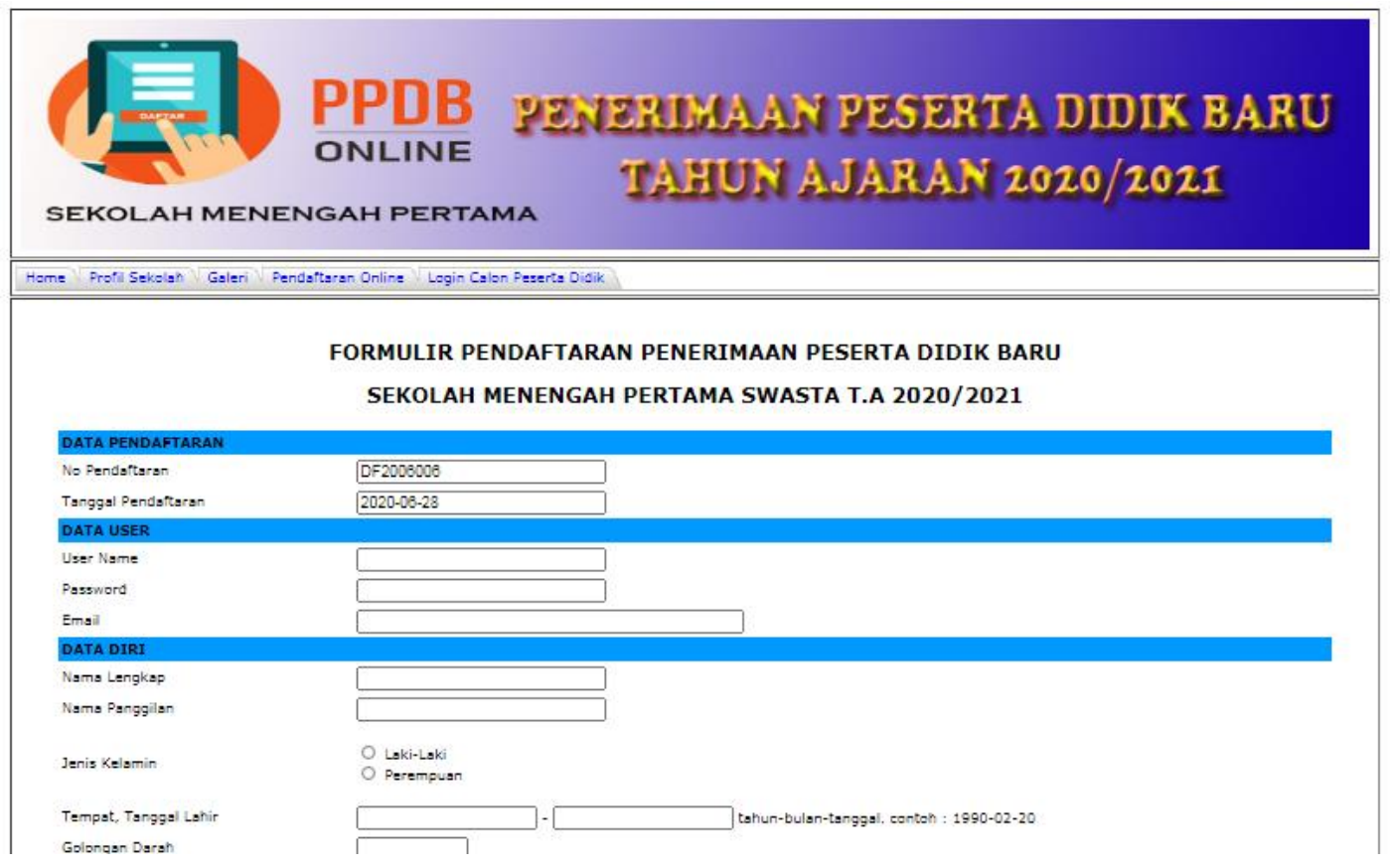

Gambar 7. Halaman Pendaftaran Onlline

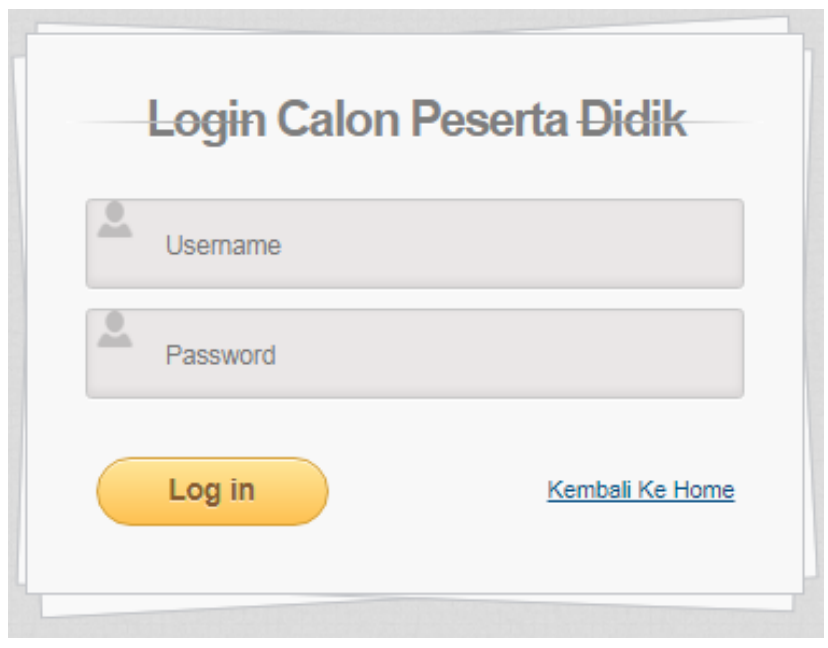

Gambar 7. Halaman Login Calon Peserta Didik

\section{Black Box Testing}

Pengujian dilakukan terhadap program yang dibuat menggunakan blackbox testing yang fokus terhadap proses masukan dan keluaran program.

Tabel 1. Hasil Pengujian Black Box Testing Halaman Login User

\begin{tabular}{|l|l|l|l|l|l|}
\hline No & \multicolumn{1}{|c|}{$\begin{array}{c}\text { Skenario } \\
\text { pengujian }\end{array}$} & Test case & \multicolumn{1}{|c|}{$\begin{array}{c}\text { Hasil yang } \\
\text { diharapkan }\end{array}$} & $\begin{array}{c}\text { Hasil } \\
\text { pengujian }\end{array}$ & Kesimpulan \\
\hline 1. & $\begin{array}{l}\text { Username dan } \\
\text { password kosong, } \\
\text { klik tombol Login }\end{array}$ & $\begin{array}{l}\text { Username: } \\
\text { (kosong) } \\
\text { Password : } \\
\text { (kosong) }\end{array}$ & $\begin{array}{l}\text { Sistem akan } \\
\text { menolak akses dan } \\
\text { menampilkan } \\
\text { "LOGIN GAGAL" }\end{array}$ & $\begin{array}{l}\text { Sesuai } \\
\text { harapan }\end{array}$ & Valid \\
\hline 2. & $\begin{array}{l}\text { Username diisi } \\
\text { dan password }\end{array}$ & $\begin{array}{l}\text { Username: } \\
\text { siti }\end{array}$ & $\begin{array}{l}\text { Sistem akan } \\
\text { menolak akses dan }\end{array}$ & $\begin{array}{l}\text { Sesuai } \\
\text { harapan }\end{array}$ & Valid \\
\hline
\end{tabular}


IJSE - Indonesian Journal on Software Engineering, Vol.6, No.2, Desember 2020, 182-194

\begin{tabular}{|c|c|c|c|c|c|}
\hline & $\begin{array}{l}\text { kosong, klik } \\
\text { tombol Login }\end{array}$ & $\begin{array}{l}\text { Password: } \\
\text { (kosong) }\end{array}$ & $\begin{array}{l}\text { menampilkan } \\
\text { "LOGIN GAGAL" }\end{array}$ & & \\
\hline 3. & $\begin{array}{l}\text { Username kosong } \\
\text { dan password } \\
\text { diisi, klik tombol } \\
\text { Login }\end{array}$ & $\begin{array}{l}\text { Username : } \\
\text { (kosong) } \\
\text { Password : } \\
123 \text { (benar) }\end{array}$ & $\begin{array}{l}\text { Sistem akan } \\
\text { menolak akses dan } \\
\text { menampilkan } \\
\text { "LOGIN GAGAL" }\end{array}$ & $\begin{array}{l}\text { Sesuai } \\
\text { harapan }\end{array}$ & Valid \\
\hline 4. & $\begin{array}{l}\text { Mengisi data } \\
\text { username yang } \\
\text { salah dan mengis } \\
\text { data pada } \\
\text { password, klik } \\
\text { tombol Login }\end{array}$ & $\begin{array}{l}\text { Username: } \\
\text { siti (benar) } \\
\text { Password: } \\
123456 \\
\text { (salah) }\end{array}$ & $\begin{array}{l}\text { Sistem akan } \\
\text { menolak akses dan } \\
\text { menampilkan } \\
\text { "LOGIN GAGAL" }\end{array}$ & $\begin{array}{l}\text { Sesuai } \\
\text { harapan }\end{array}$ & Valid \\
\hline 5. & $\begin{array}{l}\text { Mengisi kondisi } \\
\text { salah pada } \\
\text { username, klik } \\
\text { tombol Login }\end{array}$ & $\begin{array}{l}\text { Username: } \\
\text { sitiss(salah) } \\
\text { Password: } \\
123 \text { (benar) }\end{array}$ & $\begin{array}{l}\text { Sistem akan } \\
\text { menolak akses dan } \\
\text { menampilkan } \\
\text { "LOGIN GAGAL" }\end{array}$ & $\begin{array}{l}\text { Sesuai } \\
\text { harapan }\end{array}$ & Valid \\
\hline 6. & $\begin{array}{l}\text { Mengisi username } \\
\text { dan password } \\
\text { yang benar, klik } \\
\text { tombol Login }\end{array}$ & $\begin{array}{l}\text { Username: } \\
\text { siti (benar) } \\
\text { Password : } \\
123 \text { (benar) }\end{array}$ & $\begin{array}{l}\text { Sistem menerima } \\
\text { akses login } \\
\text { kemudian masuk ke } \\
\text { menu utama/ } \\
\text { halaman } \\
\text { administrator }\end{array}$ & $\begin{array}{l}\text { Sesuai } \\
\text { harapan }\end{array}$ & Valid \\
\hline
\end{tabular}

Tabel 2. Hasil Pengujian Black Box Testing Halaman Pendaftaran Sekolah

\begin{tabular}{|c|c|c|c|c|c|}
\hline No & $\begin{array}{l}\text { Skenario } \\
\text { pengujian }\end{array}$ & Test case & Hasil yang diharapkan & $\begin{array}{c}\text { Hasil } \\
\text { pengujian }\end{array}$ & Kesimpulan \\
\hline 1. & $\begin{array}{l}\text { Semua data di } \\
\text { form } \\
\text { pendaftaran } \\
\text { sekolah diisi } \\
\text { kemudian klik } \\
\text { tombol simpan }\end{array}$ & $\begin{array}{c}\text { Semua data } \\
\text { tidak terisi } \\
\text { atau } \\
\text { kosong }\end{array}$ & $\begin{array}{c}\text { Sistem akan menolak } \\
\text { akses dan menampilkan } \\
\text { pesan "Maaf data anda } \\
\text { belum lengkap. Silahkan } \\
\text { dilengkapi" }\end{array}$ & $\begin{array}{l}\text { Sesuai } \\
\text { harapan }\end{array}$ & Valid \\
\hline 2. & $\begin{array}{l}\text { Semua data di } \\
\text { form } \\
\text { pendaftaran } \\
\text { sekolah diisi } \\
\text { kemudian klik } \\
\text { tombol simpan }\end{array}$ & $\begin{array}{l}\text { Data terisi } \\
\text { dan ada } \\
\text { beberapa } \\
\text { yang } \\
\text { kosong }\end{array}$ & $\begin{array}{l}\text { Sistem akan menolak } \\
\text { akses dan menampilkan } \\
\text { pesan "Maaf data anda } \\
\text { belum lengkap. Silahkan } \\
\text { dilengkapi" }\end{array}$ & $\begin{array}{c}\text { Sesuai } \\
\text { harapan }\end{array}$ & Valid \\
\hline 3. & $\begin{array}{l}\text { Semua data di } \\
\text { form } \\
\text { pendaftaran } \\
\text { sekolah diisi } \\
\text { kemudian klik } \\
\text { tombol simpan }\end{array}$ & $\begin{array}{c}\text { Semua data } \\
\text { terisi }\end{array}$ & $\begin{array}{l}\text { Sistem akan menyimpan } \\
\text { data pendaftaran. } \\
\text { Kemudian menampilkan } \\
\text { pesan data berhasil di } \\
\text { simpan dan } \\
\text { menampilkan link untuk } \\
\text { mencetak bukti } \\
\text { pendaftaran. }\end{array}$ & $\begin{array}{c}\text { Sesuai } \\
\text { harapan }\end{array}$ & Valid \\
\hline
\end{tabular}

\section{E. KESIMPULAN}

Berdasarkan perancangan website penerimaan peserta didik baru untuk tahun ajaran 2020/2021 dapat diambil kesimpulan dalam penelitian ini adalah sebagai berikut:

1. Dengan adanya sistem penerimaan peserta didik baru berbasis online ini dapat memudahkan calon peserta didik untuk melakukan pendaftaran tanpa harus datang ke sekolah. 
2. Dengan adanya sistem penerimaan peserta didik baru berbasis online ini dapat memudahkan sekolah mengelola data penerimaan siswa baru secara efektif dan efisien sehingga data akan tesimpan dengan rapi dan tidak ada data yang hilang.

3. Dengan adanya sistem penerimaan peserta didik baru berbasis online ini dapat membantu sekolah dalam proses pemasaran atau marketing sehingga dapat menarik calon peserta didik baru untuk mendaftar di sekolah ini.

\section{REFERENSI}

Abdulloh, R. (2015). Web Programming Is Easy. Jakarta: Elex Media Komputindo.

Amin, R. (2017). Rancang Bangun Sistem Informasi Penerimaan Siswa Baru Pada Smk Budhi Warman 1 Jakarta, 2(2), 113-121.

Ardiansyah, D. (2016). Sistem Informasi Pendaftaran Event Dengan Php Untuk Panduan Skripsi. Cirebon: Asfa Solution.

Aulawi, A., \& Srinawati, S. (2019). Perancangan Sistem Informasi Penerimaan Siswa Baru Berbasis Web (Studi Kasus: Smp Plus Babussalam Bandung). Pro Patria: Jurnal Pendidikan, Kewarganegaraan, Hukum, Sosial, Dan Politik, 2 No 1.

Bekti, H. (2015). Mahir Membuat Website Dengan Adobe Dreamweaver Cs6 Css Dan Jquery. Yogyakarta: Andi.

Imaniawan, F. F. D., \& Wati, F. F. (2017). Sistem Informasi Administrasi Kependudukan Berbasis Web Pada Desa Bogangin Sumpiuh, 7(3), 1-9.

Iskandar, Y. (2018). Pengantar Aplikasi Komputer. Yogyakarta: Budi Utama.

Madcoms. (2016). Sukses Membangun Toko Online Dengan Php \& Mysql. Yogyakarta: Andi Offset.

Nisa, K., \& Supriatna, A. (2015). Perancangan Website Desa Wisata Karangrejo Sebagai Media Informasi Dan Promosi. Bianglala, 1.

Puspitasari, D. (2016). Sistem Informasi Perpustakaan Sekolah Berbasis Web, (2), 227-240.

Rerung, R. R. (2018). Pemrograman Web Dasar. Yogyakarta: Budi Utama.

Riadi, E. (2016). Statistika Penelitian (Analisis Manual Dan Ibm Spss). Yogyakarta: Andi Offset.

Rohman, F., \& Kurniawan, D. (2017). Pengukuran Kualitas Website Badan Nasional Penanggulangan Bencana Menggunakan, 3(1), 31-38.

Sasongko, A. (2017). Dan Teknologi Komputer Integrasi Data Website Students . Bsi . Ac . Id Untuk Mobile Infokampus Berbasis Android Menggunakan, 2(2), 146-155.

Sibero, A. F. (2016). Web Programming Power Pack. Yogyakarta: Mediakom.

Sukamto, R. A., \& Shalahuddin, M. (2014). Rekayasa Perangkat Lunak: Terstruktur Dan Berorientasi Objek. Bandung: Informatika.

Susilowati, S., \& Informatika, M. (2017). Pengembangan Sistem Informasi Manajemen Zakat, Infaq , Shadaqoh, Waqaf Dan Hibah Menggunakan Metode Waterfall, 19(1), 52-60.

Wahyuningrum, T., \& Januarita, D. (2017). Implementasi Dan Pengujian Web E-Commerce Untuk Produk Unggulan Desa, (May). 